\title{
The consequences of democratisation on Taiwan's daily press
}

Since the end of the 1980s, competition between papers has sharpened

Patricia R.S. Batto

\section{OpenEdition}

\section{Journals}

Electronic version

URL: http://journals.openedition.org/chinaperspectives/791

DOI: 10.4000/chinaperspectives.791

ISSN: 1996-4617

\section{Publisher}

Centre d'étude français sur la Chine contemporaine

Printed version

Date of publication: 1 February 2004

ISSN: 2070-3449

\section{Electronic reference}

Patricia R.S. Batto, «The consequences of democratisation on Taiwan's daily press », China

Perspectives [Online], 51 | january-february 2004, Online since 23 April 2007, connection on 28 October 2019. URL : http://journals.openedition.org/chinaperspectives/791 ; DOI : 10.4000/chinaperspectives. 791

This text was automatically generated on 28 October 2019

(c) All rights reserved 


\title{
The consequences of democratisation on Taiwan's daily press
}

Since the end of the 1980s, competition between papers has sharpened

\author{
Patricia R.S. Batto
}

1 Since the end of the 1980s, there has been a free press in Taiwan. Before then, the newspapers had been muzzled for almost forty years by the Nationalist regime. On an economic level, the abolition of controls has opened up the daily newspaper market to competition; on a political level, it has made it possible for all shades of opinion to be freely expressed.

2 This article seeks to examine the impact of the end of the controlling of the daily press in Taiwan, and more broadly, the links between the liberalisation of the press and Taiwan's transition to democracy. After a brief historical summary, the situation arising from liberalisation will be considered first of all through the emergence of Ziyou shibao (The Liberty Times), a daily which concentrates on "Taiwan » rather than the "Republic of China ». Then we will look at the flagship of one of the two big press groups on the island, the Lianhe bao (United Daily News), and its relations with the government. Lastly, ahead of the March 2004 elections, we will return to the positions of the main newspapers on the island during the previous presidential campaign, in 2000, at the end of which the Democratic Progressive Party (Minjindang) candidate, Chen Shuibian, was elected President, and is now seeking a second term.

The establishment of baojin

3 The system of control over the press, or baojin ${ }^{1}$, set up by the Nationalist government was based on a multiplicity of legal arrangements, and it is difficult to date its establishment exactly. Generally this is accepted to be the date of a directive of the Yuan executive, June 10 19512. Taiwan's press was subject to legislation which flowed on the one hand from the emergency regime in force on the island - especially the martial law proclaimed on May 19 1949; backed up, on the other hand, by specific laws on publications. The Nationalist regime, which had retreated from mainland china to 
Taiwan in 1949, justified the maintenance of emergency legislation by its claim to be pursuing the civil war against the communists in order to reconquer the mainland. Article 11 of the martial laws restrained the exercise of fundamental rights and liberties; in particular, it gave the military authorities the power to suppress newspapers, magazines and other printed materials «judged to be detrimental to military affairs ». A whole set of measures were linked to the martial laws, some of which dealt with the press.

4 Another important text concerning the press was the law on publications, promulgated on April $91952^{3}$. This law, which was revised to make it more restrictive in 1958, allowed the government to close a daily paper definitively and to impose all the sanctions on publications - warnings, fines, suspension or stopping of publication - by administrative means, which is to say without any judicial procedure ${ }^{4}$. This law fell into disuse after 1988, but was not repealed until January $251999^{5}$.

5 Baojin designates the entirety of the measures restraining freedom of the press:

- The limitation on the registration of new newspapers (xianzheng) was a de facto interdiction on the creation of any new newspaper. There remained the possibility of buying and transforming an existing title.

- The limitation on the pagination (xianzhang) of the existing dailies was fixed on December 1 1950 at one and a half sheets, or 6 pages for broadsheets ${ }^{6}$. The authorised pagination was only increased three times: in September 1950 to two sheets, in April 1967 to two and a half sheets, and in March 1974 to three sheets.

- The limitation on newspaper printing places (xianyin) assigned a single printing place to each daily: the distribution area of each paper, starting from a single point of departure, was thus limited.

6 Control of the press was exercise by various government organs, the two main ones being the army and the Government Information office (GIO), behind which the Central Propaganda Department of the Guomindang was at work.

7 Up to January 1 1988, when the baojin was repealed, the number of dailies in Taiwan remained constant at $31^{7}$. From 1945 to 1959 , the government press was dominant: first it was the Taiwan xinsheng bao (Taiwan Shin Sheng Daily News), published by the provincial authorities which had the largest circulation; ${ }^{8}$ then, from 1954, the flagship of the Guomindang press, the Zhongyang ribao (Central Daily News) ${ }^{9}$. But very quickly, private dailies got the upper hand. These dailies, tolerated in particular because the Nationalist government was determined to put up a good show on the international level and to ensure American support, did not belong to the government, to the Guomindang or to the army; but the authorities made sure that they were in the hands of the regime's faithful. In a symptomatic way, with rare exceptions, most of the newspapers - as well as the media in general - were then in the hands of of Mainlanders (Waishengren) ${ }^{10}$. The private newspapers, which were not subsidised, were concerned with commercial profit: thus, in 1952, the main private dailies in Taipei united against the government press in order to obtain from the authorities the publication of institutional advertising in their pages ${ }^{11}$.

8 The first private paper to develop was the Lianhe bao: on the eighth anniversary of its creation, on September 16 1959, it claimed to be the island's leading daily over the Zhongyang ribao, with a circulation of about 80,000 . A paper with a popular readership, it differentiated itself from the organs of Nationalist propaganda, specialising in short news items which the government dailies scorned. But it set itself apart in other ways: 
for example it decided to publish on its front page only important information about Chiang Kai-shek; the government dailies could not allow themselves such an innovation: they systematically published any news about the President on the front page. To a certain extent, the obligation to be profitable, the need to sell, incited the private papers to distance themselves from propaganda, while remaining within limits acceptable to the regime, in order not to end up being closed down.

Baojin led to the constitution of two big private press groups in Taiwan, that of the Lianhe $b a 0^{12}$ and that of the Zhongguo shibao (China Times) ${ }^{13}$. Jiang Jingguo, the son of Chiang Kai-shek, brought their bosses, Wang Tiwu and Yu Jizhong, both former members of the Nationalist army, into the Central Committee of the Guomindang in the 1970s.

A growth in parallel with economic expansion

At the end of the 1980s, Taiwan's daily press was extremely modern. Its plant and technology were those of a developed country, in terms of writing, editing and printing. Taiwan's dailies were in colour: the first to equip itself with colour printing facilities was the Zhongguo shibao, in March $1968^{14}$.

11 The growth of the Taiwanese press has paralleled economic expansion. The existence of newspapers calls for a fairly advanced level of development, particularly at infrastructure level. It also calls for a potential readership, which is to say a population with high levels of education. One of the key factors in the Taiwanese « miracle » has been the importance given to education, which put an end to illiteracy ${ }^{15}$.

With economic development, Taiwanese society entered the mass consumption era, and the advertising market went through a stunning expansion. Newspapers have two major sources of revenue: sales to readers and advertising (small ads and commercial advertising). The majority of Taiwan's dailies draw most of their resources from the latter: in 1960, they attracted $62 \%$ of advertising investment, and, in 1987, $41 \%$, as against the $34 \%$ accruing to television, which appeared on the island in 1962. Between 1960 and 1987, the advertising revenues of the daily press went from 102 to 9,665 million $\$ \mathrm{NT}^{16}$. In the framework of a limited pagination, such a flood of advertising obviously posed a problem. The dailies strove to meet it: no space was wasted, and advertising was to be found in the margins and even in the central folds of newspapers. Moreover, a procedure called suoban (« page reduction »), mainly applied to small ads, consisted of reducing the pointage of the characters. Over the years, the small ads were composed in progressively smaller characters until they became tiny and almost impossible to decipher. A second procedure (huanban, " changing pages ») consisted of a multiplicity of local editions. Each paper published editions different with different editorial content, as well as different small ads and different commercial advertising (especially property advertisements) ${ }^{17}$. Finally, a third procedure, called fenban («page sharing »), consisted of selling the same advertising space, on the front page for example, to two different advertisers, A and B; half the papers printed would carry advertisement $A$ and the other half, B; each sales outlet was supplied with half $A$ papers and half $\mathrm{B}$. The abolition of baojin, by putting an end to limited pagination, also finished off most of these practices.

13 Another element favoured the modernisation of the Taiwanese press: the Chinese language. As long the composition of texts was still carried out manually, one character at a time, the production conditions for publications in alphabetical languages and in Chinese were about the same. But with the automation of composition, Chinese was 
penalised by its enormous number of characters ${ }^{18}$. The computerisation of Taiwanese newspapers, which began in the early 1980s, made it possible to reduce the difference in productivity between Chinese and the alphabetical languages ${ }^{19}$.

In the 1960s, when the Taiwanese economy took off, the total circulation of the daily press doubled, from 680,000 copies in 1960 to 1.22 million in $1970^{20}$, and advertising revenues increased fivefold, from 102 million \$NT in 1960, they rose to 507 million in 1970. The appearance and content of the dailies improved, because of plant modernisation, but also because of better training for journalists. The government press was losing ground. The Lianhe bao was the leading private newspaper in terms of ciculation, closely followed by the Zhongguo shibao at the end of the decade.

In the 1970s, the total circulation of the daily press tripled, reaching 3.5 million copies in $1980^{21}$, while its advertising revenue increased eightfold over the decade to reach 4.4. billion \$NT in 1980. The Lianhe bao and the Zhongguo shibao, which, in 1979 announced that it had become the leading Taiwanese daily, shared most of the market. The success of the Zhongguo shibao can be explained in particular by a more tolerant attitude than that of the Lianhe bao in the face of increasing opposition to the Nationalist regime, at a time when the Republic of China was being isolated on the diplomatic level. In any case, over all, the daily press, which was in the hands of personalities loyal to the government, was conservative and supported the political status quo. Only two papers, held by native Taiwanese, distanced themselves from the official line, while being careful to remain within limits tolerable to the regime: the Zili wanbao (The Evening Independent) et le Minzhong ribao (The Popular Daily). The Zili wanbao, an evening daily which first appeared in Taipei on October 10 1947, played, under the aegis of Wu Sanlian ${ }^{22}$, the role of a powerhouse in the handling of political news for the press as a whole ${ }^{23}$. The Minzhong ribao, created on September 51950 in Jilong, and which set up in Gaoxiong in 1978, adopted an editorial line closely based on that of the Zili wanbao, but its quality was not as good ${ }^{24}$.

The government's control of the media produced in the 1970s a blossoming of dissident magzines on the island ${ }^{25}$. In 1975 Taiwan zhenglun (The Taiwan Political Tribune) was created, and in 1979 Bashi niandai (The Eighties) and Meilidao (Formosa) were launched ${ }^{26}$. Bashi niandai represents the opposition's moderate faction, while Meilidao was launched by the radical faction Dangwai which, at the end of the 70s, went from demands for democracy to demands for independence. On December 10 1979, International Human Rights Day, Meilidao organised a gathering at Gaoxiong which ended in an explosion of violence. Many members of Dangwai were arrested. Eight people were tried for sedition by a military court, and sentenced on April 191980 to prison terms ranging from twelve years to life. Among them was Annette Lü (Lü Xiulian), Chen Shiban's running mate in 2000, who was elected vice-president, and is running for reelection in 2004. Chen Shuiban, a lawyer, entered politics at the time of the Meilidao trial. The dissident magazines of Dangwai have played a central role in the expression as well as the organisation of political opposition, and consequently in democratization.

17 In the early 1980s, the daily press market stabilised and the Lianhebao and Zhongguo shibao groups reinforced their dominant position. In 1986, the total circulation of the daily press was estimated at 3.8 million copies $^{27}$; or about one paper for every 5 inhabitants. The Taiwanese, with some 208 dailies sold per 1,000 inhabitants, read fewer newspapers than the Japanese, the biggest consumers of dailies along with the Scandinavians (in the early 1990s: 562 copies per 1,000 inhabitants) or the Americans 
(244), but more than the French (155) or the Italians (118). The Taiwanese advertising market continued to grow; between 1980 and 1987, the advertising revenue of the daily press more than doubled. On the eve of January 1 1988, the circulation of the Zhongguo shibao was estimated at 1.2 to 1.3 million copies and that of the Lianhe bao at 1.1 million ${ }^{28}$. The totality of the dailies published in Taiwan by the two groups represented $80 \%$ of total circulation and corresponded to $55 \%$ of daily press advertising revenue.

After 1988, the profusion of titles conceals the concentration of the market

Baojin came to an end on January 1 1988, but an important step towards freedom had already been taken with the lifting of martial law on the island on July 151987 . The number of registered newspapers, limited to 31 for almost forty years, rose to 122 in 1988 and reached 454 in 2001.

These papers however cover very different realities: advertisers, for their part, take only twenty dailies into consideration. After 1988, the advertising market, which had reached a degree of saturation, no longer showed the same growth as before. And in 1996, for the first time, television overtook the daily press in advertising revenue. The growing interest of advertisers is explained by the growth of cable from 1995 on, but also by the decline of the dailies' readership. The number of people who read a daily fell from $76 \%$ to $57 \%$ between 1991 and $2001^{29}$. This decline is thought to be due to the young generations who prefer other media, such as television and the Internet, but may also reflect discontent, in particular in the face of a drift to sensationalism.

1 The share of advertising between the daily press and television

\begin{tabular}{|c|c|c|c|c|}
\hline Year & $\begin{array}{l}\text { Total number } \\
\text { of papers } \\
\text { registered }\end{array}$ & $\begin{array}{l}\text { Total } \\
\text { advertising } \\
\text { revenue } \\
\text { (millions of NTs) }\end{array}$ & $\begin{array}{l}\text { Share } \\
\text { of the } \\
\text { daily press } \\
\text { (in } \% \text { ) }\end{array}$ & $\begin{array}{l}\text { Share } \\
\text { of } \\
\text { television } \\
\text { (in \%) }\end{array}$ \\
\hline 1988 & 122 & 37469 & 43 & 31 \\
\hline 1989 & 195 & 48009 & 43 & 30 \\
\hline 1990 & 211 & 49838 & $40 I$ & 321 \\
\hline 1991 & 237 & 54659 & 39 & 33 \\
\hline 1992 & 270 & 70111 & 40 & 32 \\
\hline 1993 & 274 & 74796 & $37 \mid$ & 33 \\
\hline 1994 & 300 & 83674 & 37 & 35 \\
\hline 1995 & 335 & 52513 & 40 & 30 \\
\hline 1996 & 362 & 41094 & 39 & 511 \\
\hline 1997 & 344 & 48585 & 37 & 53 \\
\hline 1998 & 368 & 61876 & 34 & 57 \\
\hline 1999 & 384 & 59339 & 32 & 55 \\
\hline 2000 & 445 & 58926 & 321 & 52 \\
\hline 2001 & 454 & 52846 & 31 & 53 \\
\hline
\end{tabular}

Sources: Chuban nianjian. Zhonghua minguo jiushiyi nian (Publications Yearbook. Republic of China 2002), Taipei, Executive Yuan, Government Information Office, 2003. Zhonghua minguo guanggao nianjian 94-95 (Advertising Yearbook of the Republic of China 1994-1995), pp. 24-26, for the period 1988-1994. Zhonghua minguo guanggao nianjian 1997-1998, p. 164 and p. 169 for 1995 and 1996. Zhonghua minguo guanggao nianjian 2001-2002, p. 226 for the period 1997-2001. 

their positions. In 2001, the Lianhebao group took $38.5 \%$ of advertising revenues and Zhongguo shibao $30 \%$; between them they took $68.5 \%$ of the market ${ }^{30}$, compared to $55 \%$ held before liberalisation ${ }^{31}$. First the two groups created new newspapers: by 1988 they had established a foothold in the evening daily slot. Then they considerably increased their pagination: their flagships, the Lianhe bao and the Zhongguo shibao, with 12 pages prior to 1988 , increased to fifty pages during the presidential election in March $2000^{32}$. Lastly both companies built new printing works in the north, centre and south of the island: to meet the increases in pagination, but also to better establish themselves locally through an increase in local editions, to facilitate their distribution and improve their tapping of the advertising market. Obviously the financial and technical means at their disposal (established distribution networks, for example), as well as their knowhow, gave them an advantage over newcomers. The oligopolistic situation which prevailed before 1988 therefore favoured concentration.

The major resources needed for the creation of a newspaper and the keen competition as a result of liberalisation explain the short lifespan of many dailies. An example is the Shoudu zaobao (The Morning of The Capital) launched on May 41989 by Kang Ninxiang, a key figure in the opposition, who was behind the magazines Taiwan zhenglun and Bashi niandai. The Shoudu zaobao, with 12 pages at 8 \$NT, looked " poor " compared to the Zhongguo shibao, for example, at 10 \$NT, which on January 11988 went up to 24 pages and whose pagination has constantly increased. On August 28 1990, in a « Note to our readers " on the front page, Shoudu zaobao announced that it was ceasing publication " momentarily» for « financial reasons ", and disappeared after some sixteen months of existence. Yet it reflected without any doubt a section of Taiwanese opinion.

After liberalisation, the difference between "national» dailies (those newspapers registered in Taipei) and the «local » dailies, tended to diminish. The quantity of local news published in the multiple editions of the major papers, was equivalent to that of the local papers, sometimes with an even finer division of the territory into constituencies. The difference between "general» and «specialised» papers also became increasingly blurred: all the Taiwanese papers filled out their content thanks to increases in pagination, thus including more economic or leisure news than before. Local and specialised papers, along with the government press with its unattractive content, were hit hard.

The lifting of baojin sounded the death-knell of the dissident press as well, and affected a paper like the Zili wanbao. On September 281986 was born the Democratic Progressive Party which brought together various factions of the Dangwai: the opposition no longer needed a journalistic cover for its political activities; moreover, the legalisation of the opposition led to an improvement in the coverage of its activities by the media. It became more difficult for dissident magazines to have subversive content. The Zili wanbao, whose publishing company launched a morning daily The Zili zaobao (The Morning Independent) on January 1 1988, was also losing ground. On the one hand, because of liberalisation, its editorial line lost some of its originality and thus some of its attraction. On the other hand, the lifting of baojin having made it possible for the two major groups to gain a foothold in the evening daily sector, the Zili zaobao found itself directly confronted with the two giants. The Zili zaobao closed in February 1999 and the Zili wanbao disappeared in the autumn of $2001^{33}$. Lastly, the general dailies,

China Perspectives, 51 | january-february 2004 
because of the frenetic competition between them, tended to fall into line with each other. Liberalisation has therefore been a source of standardization.

The rise of the Ziyou shibao out $^{37}$. The Ziyou shibao gave greater importance to "Taiwan " over the "Republic of China », emphasized local difference (bentuhua), and « roots » (caogen). Its slogan, in its promotional campaigns, was: « Taiwan above all, priority to freedom » (Taiwan youxian, ziyou di yi). Lin Rongsan's daily aligned its positions on those of the Democratic Progressive Party, thus setting itself apart from the Lianhe bao and the Zhongguo shibao. In parallel, it gave unconditional support to Li Denghui, the first islander to be President of the Guomindang.

ou shibao experienced spectacular growth and, in June 1989, moved into the city of Taipei. On June 15 1999, Lin Rongsan launched an English language daily, The Taipei Times, thus creating the Ziyou shibao group. The spectacular growth of the Ziyou shibao 
was linked to its new format, the reason generally given by its supporters. But it also owed much to an aggressive and much-criticized commercial policy, not to mention Lin Rongsan's sizeable financial resources and political support, being close to Li Denghui and very active in the paper from the beginning of the $1990 \mathrm{~s}^{38}$.

The exacerbated competition to be the leading Taiwan daily

After 1988, in the absence of an organisation to measure circulation in Taiwan ${ }^{39}$, the main reference was the readership rates of the dailies, measured by a private polling institution and aimed at advertising professionals ${ }^{40}$. The Ziyou shibao's readership went from $4.1 \%$ to $21.7 \%$ in 1996 , the year in which he claimed the title of Taiwan's leading daily.

2 Readership rates of the three main Taiwanese dailies (in \%)

\begin{tabular}{lrrrrrrrrrrrr}
\hline Title & 1991 & 1992 & 1993 & 1994 & 1995 & 1996 & 1997 & 1998 & 1999 & 2000 & 2001 & 2002 \\
\hline Lianhe boo & 29.6 & 30.7 & 26.6 & 25.2 & 24.8 & 20.8 & 21.4 & 21.1 & 19.5 & 17.9 & 15.3 & 13.7 \\
Zhongguo shibao & 27.2 & 26.3 & 26.2 & 24.9 & 22.6 & 19.1 & 20.5 & 21.2 & 18.6 & 17.6 & 15.6 & 15.2 \\
Ziyou shibao & 4.1 & 6.4 & 12.7 & 14.1 & 14.2 & 21.7 & 25.3 & 25.3 & 24.4 & 23.2 & 21.7 & 19.1
\end{tabular}

Source: Zhonghua minguo guanggao nianjian 2001-2002 (Advertising Yearbook of Taiwan, The Republic of China, 2001-2002), Taipei, Taibeishi guanggao daili shangtongye gonghui, 2003, p.233, and ACNielsenMedialndex.

31 Immediately after the liberalisation, the Linhe bao and the Zhongguo shibao were faced with a steep decline in sales. In the space of a few months, both publications doubled not only their pagination, but also their price: on September 1 1987, they went from 12 to 20 pages and from 5 to $8 \$ \mathrm{NT}$. Both papers' circulation fell below a million copies between January and April $1988^{41}$. The rise in prices seems to have played a decisive role in this fall: before $1988,40 \%$ of Taiwanese subscribers to a daily subscribed to both the Lianhe bao and the Zhongguo shibao; only $10 \%$ of them did so at the beginning of the 1990s. In January 1996, the Lianhe bao and the Zhongguo shibao raised their prices again, from 10 to $15 \$ \mathrm{NT}$, because of rising paper costs, and saw another fall in sales. That year the readership rate of the Lianhe bao went from $24.8 \%$ in 1995 to $20.8 \%$, and that of the Zhongguo shibao from $22.6 \%$ to $19.1 \%$. In contrast, the Ziyou shibao, which held its price at $10 \$ \mathrm{NT}$, saw its readership jump from $14.2 \%$ to $21.7 \%$.

But the success of the Ziyou shibao cannot be explained by its price alone. In July 1997, the monthly Tianxia published a dossier criticising the methods used by Lin Rongsan's daily to obtain its good results, in particular the large-scale distribution of free copies ${ }^{42}$. The Ziyou shibao was said to distribute up to 300,000 copies free; the Lianhe bao and the Zhongguo shibao, for their part, up to 100,000 copies $^{43}$. Meanwhile the Ziyou shibao had adopted an aggressive distribution policy, buying over the employees of the Lianhe bao and the Zhongguo shibao distribution network by paying them better. In the centre of the island, the Ziyou shibao is said to have used the distribution networks of its two competitors, by arranging for every subscriber to the Lianhe bao and the Zhongguo shibao to be also distributed, free of charge, a copy of Ziyou shinbao. When in 1996 the price of the first two papers rose from 10 to 15 \$NT, many of those who previously received the Ziyou shibao free of charge, subscribed to it at its unchanged price of 10 \$NT.

33 The final objective of this policy of low cover prices and distribution of free copies is the advertising market; the readership rate, which is the point of reference for advertising professionals, serves in particular to set the price of advertisements. When the results of the first 
quarter of 1996 were published, the Ziyou shibao raised its advertising rates. At the end of May 1997, after having registered the highest readership rates for four consecutive quarters, the Ziyou shibao aligned its prices on those of the Lianhe bao and the Zhongguo shibao. The Ziyou shibao's turnover, which was less than 2 billion $\$ N T$ in 1995, was said to have risen to around 2.9 billion in 1996, most of the rise being due to increased advertising revenue. However, according to Tianxia, the Ziyou shibao remained in the red ${ }^{44}$. The Lianhe bao, whose turnover was said to be around 8.9 billion $\$ N T$ in 1996, showed a profit of more than 700 million, and the Zhongguo shibao a profit of 20 million $\$ N T$ on a turnover of 8 billion. Faced with the rise of the Ziyou shibao, the Lianhe bao and the Zhongguo shibao were said to distribute up to 100,000 free copies each, which amounted to costs of 25 to 30 million $\$ N T$ per month. They also launched spectacular promotion campaigns, based on those of the Ziyou shibao ${ }^{45}$. Smaller papers, such as the local dailies, were severely affected by the fierce struggle between the three majors.

After the publication of the dossier by Tianxia in July 1997, the Ziyou shibao sued the mamgazine for libel, but lost the case. The verdict was handed down on December 23 1999: Tianxia was found not guilty, the court deciding that the magazine had not intented to cause harm. Meanwhile the debate had shifted - somewhat hypocritically - onto the question freedom of the press, along the lines of: how far can a news organ push criticism without being penalised by the authorities? Once the verdict was made public the Lianhebao and Zhongguo shibao groups congratulated themselves on the prevalence of press freedom in Taiwan. After 1996, the Ziyou shibao remained the leading Taiwanese daily ; but from 1999 on, its readership began to erode. Also its advertising revenues remains smaller than that of its competitors: in 2001 they amounted to $18 \%$ of the market, as against $25 \%$ for the Lianhe bao and $24 \%$ for the Zhongguo shibao.

Another consequence of the fierce competition born of liberalisation was an increasingly marked propensity to sensationalism, in order to entice readers. The lack of press ethics can also be explained by the growth in the numbers of newspapers; after liberalisation the various media recruited massively, leading to a lack of professionalism among journalists, some of whom had no training.

In 1997, in order to counter the erosion in its readership, the Zhongguo shibao resorted to a change in editorial policy with disastrous results. In 1995, the Hong Kong businessman Jimmy Lai (Li Zhiying) had launched the daily Pingguo ribao (The Apple) in the British colony, which by 1996, was threatening the leading Dongfang ribao (The Orient) ${ }^{46}$. In early 1997, the directors of the Zhongguo shibao, impressed by this success, undertook a radical reform inspired by the Hong Kong daily. The Zhongguo shibao set out to seduce the Taiwanese by choosing a more " popular » orientation. In FebruaryMarch 1997, short news items appeared on the front page. On pages 2 and 3, traditionally reserved for important news, people features cropped up.

This new editorial policy lasted until the aftermath of the kidnapping of the daughter of a television star, who was murdered by her kidnappers, and whose body was found on 28 April 1997. The Zhongguo shibao published on its front page a photograph of the body, with a closeup of the hand from which the kidnappers had severed a finger, and, on page 2, a romanticized article about the case. This treatment of the news raised an outcry on the island; a number of scandalised readers protested and cancelled their subscriptions. The Zhongguo shibao was stigmatized in the schools of journalism. After this case, the daily abandoned its new editorial line. 
Relations between the press and the authorities, and the boycott of the Lianhe bao in 1992

The coming to power of Li Denghui in 1988 marked a change in relations between the authorities and the media: the traditional themes of "the national interest " and of « the mission of the press » were repaced by « the importance of establishing a modern society and the rule of law ", to quote the President's own words during an interview with media owners who were members of the Guomindang on April 19 1989. Even though the media's role as " guide of public opinion » was still mentioned, after 1988, they were no longer asked so much to promote the policy of the Guomindang or of the State, as to respect certain ethical criteria.

In a text published on Spetember 11989 in the Zhongyang ribao, and entitled "Observations and suggestions to the media after the lifting of martial law", the Director of the Government Information Office (GIO), Shao Yuming called for selfregulation of the media: "One can distinguish self-regulation from the discipline imposed by regulations. Discipline stems from the laws, codes and pressure groups which defend the public interest. These two forms of discipline are not incompatible, but the former is better... for it has no influence on the freedom of the press. Where discipline is concerned we should first reinforce the role of the Media Council ${ }^{47}$. The government is in fact under the surveillance of the media, and it is not suitable for the government to use administrative means or the law to punish them. That would raise criticisms about freedom of the press being hampered». It was one of the first times that a member of the government looked upon the media as an independent power - whose functions include keeping an eye on the government - and declared that the government should not intervene in the area of the media ${ }^{48}$.

40 After the lifting of martial law and up to the abrogation of the Law on publications in 1999, the GIO, which still had the power to monitor the press, only claimed a restricted role. According to its Director, Shao Yuming: «The GIO has contributed to national policy over some forty years. However, in parallel with the democratic development of our country, the GIO's role should be simplified: instead of being both government spokesman, in charge of political propaganda and responsible for press regulation, it should only keep its function as government spokesman. We should leave press regulation to the press itself. A civil entity such as the press should be regulated according to its own norms and professional ethics, and not by the government $»^{49}$.

41 According to Zhu Jiying, Director of the Guomindang's Cultural Affairs Department, which is to say the party's propaganda, «in a democratic society, the press is the spokesman of the public and represents the public's interests. I believe that the role of the party's spokesman is to provide information, not to control the news. He must manage information, not control it. He must explain the party's policy to the media and relay public opinion to his superiors. The rigid, domineering political style is out of date $»^{50}$.

However, while the press had more freedom than ever before, one daily, the Lianhe bao, had all sorts of problems with the authorities. Created in 1951, and viscerally anticommunist, the Lianhe bao distinguished itself from the 1970s onwards by its hostility to the Dangwai ${ }^{51}$, whereas in the early 1960 s it had been in favour of the creation of an opposition party. While continuing to state its attachment to democracy and to a multiparty system, the daily adopted a hard-line attitude towards the Dangwai, which initially called for the democratization, and then - as it became more radical - the 
independence of Taiwan: the Lianhe bao claimed to support the Republic of China and its founding dogma, particularly the fight against communism and the reunification of Taiwan with the mainland « under the banner of democracy ». By the end of the 1970s, the Lianhe bao used the threats of Beijing, and played on the feelings of insecurity, in order to combat the independence movement.

On October 29 1992, Li Ruihuan, a permanent member of the Political Bureau of the Chinese Communist Party, invited representatives of the overseas Chinese media, from Taiwan, Hong Kong and Macau, to Beijing. The interview drew to a close with a question from a Taiwanese, who asked how Communist China would react if the Taiwanese independence movement were to become a threat to reunification ${ }^{52}$. $\mathrm{Li}$ Ruihuan's answer was published the next day by the entire Taiwanese press. The Lianhe bao's front page headline on Ocotber 301992 ran: «Li Ruihan: continental China is prepared to interrupt its economic reconstruction to prevent the independence of Taiwan. Continental China will use " all means » to preserve the territorial integrity of the country, and will go without hesitation as far as «shedding blood and sacrificing lives » (...) ». Three other dailies gave over their front pages to Li Ruihuan's statement: the Zhonnguo shibao and two government newspapers, the Zhongyang ribao and the Taiwan xinsheng bao. In the Ziyou shibao and the Zili wanbao, the news appeared respectively on page 2 and page 3 . The various Taiwan dailies did not therefore accord the same importance to Li Ruihuan's statement, and the Lianhe bao was undeniably the paper which gave it the most prominence; but the difference in hierarchisation was not great and the content of the articles - which was purely factual - was almost identical.

On November 11 1992, the Permanent Committee of the Guomindang met to discuss relations between the two shores; one of its members, Shen Changhuan, brandishing the Lianhe bao of October 30 as evidence, was of the opinion that Li Ruihuan's remarks proved that adopting the policy of «One China, One Taiwan » would lead the island to disaster. President Li Denghui retorted: "The recent statement by Li Ruihuan in Communist China, as far as I know, does not correspond at all to what Mr Shen said. Those journalists who were present then can testify. But a person from a certain newspaper, on his return, gave a frightening account of it, to put fear into our population. (...) According to Comrade Shen, Li Ruihuan stated that he wished to set Taiwan awash in blood and renounce economic development. In reality Li Ruihuan did not say that ...53. Li Denghui's answer is surprising: on October 30 the entire Taiwanese press had attributed the same remarks to Li Ruihuan. Li Denghui did not, however, state the name of the newspaper in question.

On November 23, fifteen associations launched a "Boycott movement to save Taiwan » (tuibao jiu Taiwan yundong), against the Lianhe bao. The three most important among them were: the Association of Taiwanese Professors (Taiwan jiaoshou xiehui), the Presbyterian Church (Taiwan jidujiao zhanglaojiaohui), and the League of the Taiwanese medical world (Taiwan yijie lianmeng). At a press conference, the organisers of the movement invoked the struggle for freedom of the press. In their opinion, the media clung to their editorial lines in defiance of any objectivity, all the more so as they tended to blend fact with opinion. Moreover the organisers called for "genuine competition in the daily newspaper market "; the newspapers distributed aboard aircraft as well as those to which the public service subscribed were, they said, all in the same vein. Finally, they severely criticised the journalists, as poorly trained and under the heel of the press bosses. The initiators of the boycott stated that their 
movement was not political, that it was aimed at the media as a whole, not especially at the Lianhe bao, but they targeted the Lianhe bao because it was the biggest Taiwanese media, and because the articles it published on mainland china caused problems.

The leaflets and other materials aimed at convincing people to participate in the boycott explained that the Lianhe bao " harmed Taiwan's stability " by making itself "the spokesman of Communist China " and by being "so to speak the Taiwanese edition of the People's Daily »! These allegations, although surprising at first glance, are less so if one bears in mind the pro-unification positions of the Lianhe bao. The attack on the daily which " generates fear and threatens the Taiwanese population " was launched on two fronts simultaneously: on the readership and on the advertising. Stickers for letterboxes and entrance doorways were distributed, which proclaimed: «In our house we don't read the Lianhe bao ». The initiators of the boycott tried to persuade people not to place small ads in the Lianhe bao any more, and advertising companies and professionals not to buy any more space in it; in particular, they threatened to boycott products which appeared on the front page of the newspaper. On December 3, the boycott organisers placed an advertisement in four dailies, the Ziyou shibao, the Zili zaobao, the Zili wanbao, and the Minzhong ribao which stated: «In our house we do not read the Lianhe bao : if you advertise in it, it's in vain ».

These four papers had supported the boycott as early as November 24, by more or less adopting the movement's ideas. Moreover, on November 25, the Progressive Democratic Party (PDP) reacted favourably to the boycott, by deciding not to advertise in the Lianhe bao any longer. On December 8, the organisers asked the Guomindang to follow the PDP's example ${ }^{54}$; three arguments were advanced: the Lianhe bao was " commonly considered to be the most conservative Taiwanese newspaper", was situated "on the extreme conservative right», a position in complete contradiction with the "innovation » advocated by the Guomindang; the Nationalist party wanted stability and prosperity, whereas the Lianhe bao was a troublemaker; it asked people to have confidence while the Lianhe bao struck terror into them, "so much so that that even the leaders of the Guomindang are no longer able to put up with the ill-feeling disseminated by the Lianhe bao $"$ " .

On December 4 1992, the Lianhe bao lodged a complaint before the Media Council against the Ziyou shibao, the Minzhong ribao, the Zili zaobao and the Zili wanbao, for noncompliance with professional ethics in their coverage of, and their commentary on, the "Boycott movement to save Taiwan ». And on December 29, it sued four people for libel: the President and Secretary of the Taiwanese Professors Association, both of whom taught at Taida, the island's most prestigious university; the President of the League of the Taiwanese medical world; and a pastor of the Presbyterian church. On July 20 1993, the four accused were found guilty: the first was sentenced to five months in jail and the three others to 50 days detention. However they appealed and won: on August 24 1994, all four were declared innocent. The Media Council, which on April 1 $1993 \mathrm{had}$ announced that it was postponing the publication of the decision it had come to on March 25, in order not to influence the legal action under way, published it on February 9 1995: it found it favour of the Lianhe bao against the other papers, which were reprimanded.

49 The exact impact of the boycott is difficult to estimate, but it appears to have amounted to a major shock. First of all on the psychological plane: years later, the managers of the Lianhebao group could not get over having been called «communists». The 
participants in the boycott included all the opponents of the nationalist regime, whether pro-independence or not, on whom the paper had heaped criticism for years. But also Li Denghui - who was President of both the Republic and the Guomindang and his allies: consequently a number of administrations cancelled their subscriptions ; the airline Eva Air stopped distributing the group's newspapers on its aircraft ${ }^{56}$, etc. Between 1992 and 1993, the Lianhe bao's readership fell from $31 \%$ to $27 \%$, a fall which seems due to the boycott, for during the same period, the readership of the Zhongguo shibao remained stable, while that of the Ziyou shibao jumped spectacularly from $6 \%$ to $13 \%$. To the loss of readership must be added the slowing of the Lianhe bao's advertising revenues: these rose by only 14.6 million \$NT between 1992 and 1993, where at the same time those of the Zhongguo shibao grew by 59.5 million and those of the Ziyou shibao by 48.5 million. All in all, the boycott seems to have caused considerable losses to the Lianhebao group.

The boycotting of the Lianhe bao was only one episode in a wider power struggle. In 1990, Li Denghui, preoccupied with winning the support of the conservative mainland faction of the Guomindang, had appointed as head of the government the former Army Supreme Commander and Minister of Defence, Hao Bocun, who was close to the directors of the Lianhebao group. This appointment had caused much discontent; and the debates within the Guomindang about the policy to follow in relation to mainland China exacerbated passions. The Lianh bao seems to have served, in some ways, as a scapegoat. On the other hand, the attacks on the paper prove that it is also a major player on the Taiwanese political scene. On February 27 1993, Li Denghui rid himself of Hao Bocun and replaced him with Lian Zhan, a Taiwanese banshan ${ }^{57}$. Thereafter, the conservative mainland faction was increasingly sidelined within the Guomindang, and native Taiwanese came to power: on August 10 1993, there was a split within the Nationalist party, with the creation of the Xindang which essentially brought together young mainland politicians; in December 1995, Hao Bocun was excluded from the Guomindang, followed, in November 1999, by Song Chuyu. Li Denghui preferred Lian Zhan as candidate in the presidential elections in 2000 , which indisputably contributed to the victory of the Progressive Democratic Party's candidate, Chen Shuibian. Moreover, Li Denghui's attitude in the debate over independence or reunification has always been ambivalent. One could judge as early as 1995 that there were two positions on the question of relations between Taiwan and mainland China which contained "numerous elements of convergence", those of the majority current in the Guomindang (the faction behind Li Denghui) and that of the Progressive Democratic Party ${ }^{58}$. All things which, obviously, could only profoundly displease the Lianhe bao.

51 In the eyes of the directors of the Lianhebao group, the boycott was launched at the instigation of Li Denghui ${ }^{59}$. At the end of the boycott, followed by the dismissal of Hao Bocun, the Lianhe bao became an oposition paper, anti-Li Denghui. The daily accused the President of "anti-democratic practices", of being "dictatorial», and of not respecting the freedom of the press ${ }^{60}$. Its editorial position became radicalised, at the risk of reflecting only a minority of opinion in Taiwan and of marginalising itself by alienating the less conservative fringe of its readership. Indeed, Li Denghui then enjoyed wide popular support and indisputable legitimacy: in March 1996, he was reelected to the Presidency of the Republic for four years, by direct universal suffrage. Up to 2000, the Lianhe bao's editorials displayed a belligerent opposition verging on hysteria, with regard to Li Denghui. Under Chiang Kai-shek, a newspaper so virulent towards the authorities would not have survived. Thus, freedom of the press now 
indisputably prevailed in Taiwan; the newspapers participated fully in a sometimes intense political debate.

The Presidential election in March 2000

In March 2000, the victory of Shen Shuibian, the Progressive Democratic Party (PDP) candidate in the Presidential election, brought to an end over half a century of Nationalist government in Taiwan. His two main rivals were Lian Zhan, the official Guomindang candidate, and Song Chuyu, who had been excluded from the Nationalist Party and ran as an independent ${ }^{61}$. Chen Shuibian obtained $39.3 \%$ of the vote, barely 300,000 votes more than Song Chuyu who received $36.8 \%$ of the vote, but far ahead of Lian Zhan with $23.1 \%$ of the vote ${ }^{62}$. In March 2004, Chen Shuibian, who is seeking a second term with his running mate Annette Lü, will once again have as main rivals Lian Zhan candidate for President, allied this time with Song Chuyu, who is running for vicepresident.

During the presidential election in 2000, the Ziyou shibao, the Zhongguo shibao and the Lianhe bao devoted comparable space to the event. The Zhongyang ribao, the Guomindang daily, on the other hand devoted a proportionately much larger space to the election, because of its low pagination ${ }^{63}$. The four generalist Taiwanese newspapers devoted their front pages to the presidential election, with pages 2 and 3 being traditionally where important news appears. We have studied the first three pages of these four dailies from March 13 to 19, which is to say before and after the results of the election were made known, on March 19. All the articles on the front page concerning the election were taken into account, but only the headlines and the editorials on the two following pages. We estimated each time whether they were partisan or not, and if so in whose favour, and we measured their surface area. By adding up the positive and negative occurrences of each candidate, we determined which of the three candidate each paper favoured. The surfaces areas corresponding to the occurrences allowed us to refine the result ${ }^{64}$, on the hypothesis that an occurrence equivalent to a small surface has less impact than another which equals a large surface ; moreover, a big surface devoted to a candidate, even if it judges him negatively, gives him notoriety, and even recognition, in virtue of the principle dear to advertising professionals according to which it is better to be criticised than to be ignored, the main thing being to " exist in the media ». Finally the proportion of neutral surface area to the total area studied made it possible for us to evaluate whether a newspaper was fairly « engagé » or not. 


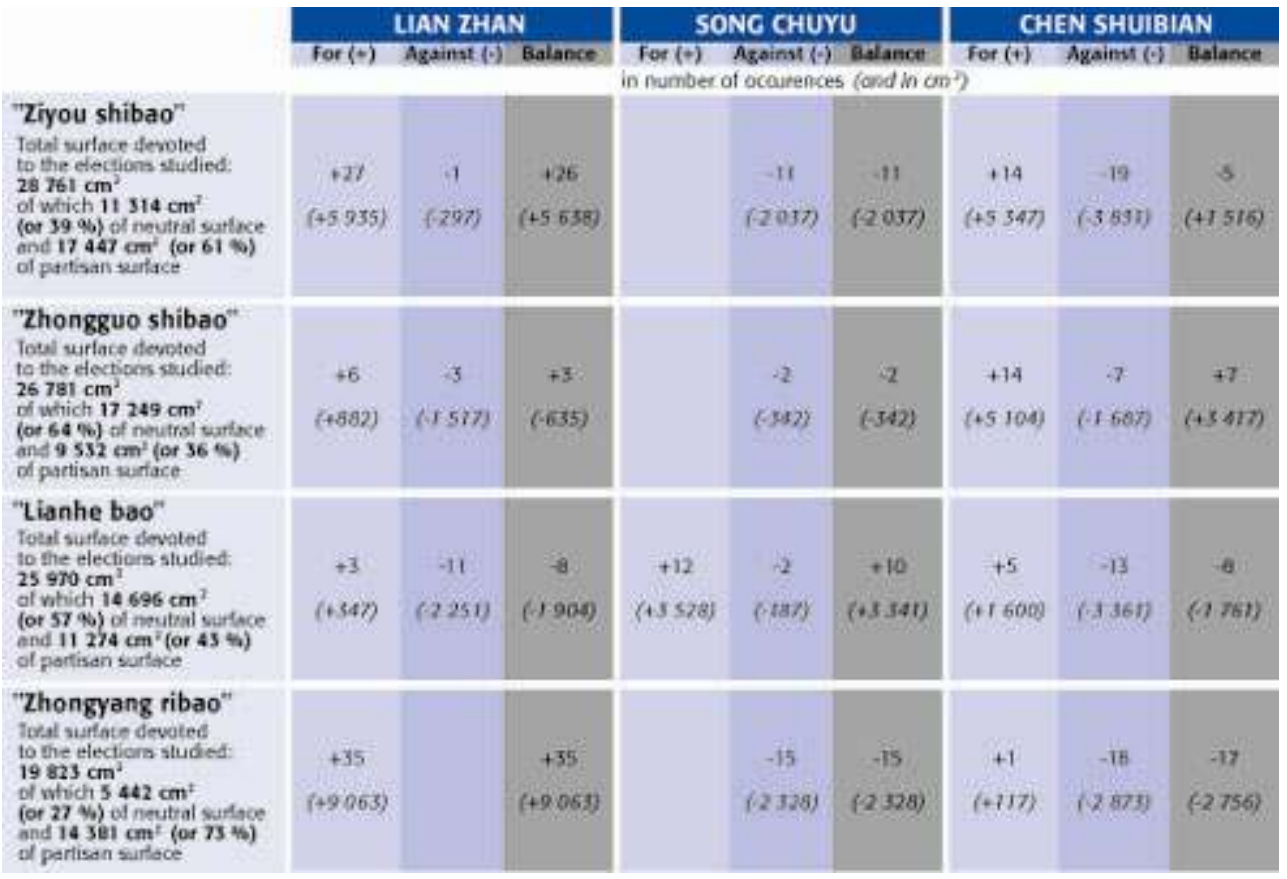

Source: Edited by the author

The Ziyou shibao was resolutely in favour of Lian Zhan, the candidate of the Guomindang. That the champion of Taiwanese nationalism chose to support Lian Zhan rather than Chen Shuibian seems to be directly linked to the friendship between its boss, Lin Rongsan, and Li Denghui. Lian Zhang shows a score of +26 , with virtually no criticism made of him. Meanwhile, the daily was very anti-Song Chuyu : when he was mentioned at all, it was in an entirely negative way $(-11)$; this is hardly surprising since it is well known that Lin Rongsan and Song Chuyu have no liking for each other ${ }^{65}$. The Ziyou shibao's attitude to Chen Shuibian seems to have been more mitigated: predominantly negative before his election ( +7 as against -19 , between March 13 and 18), it became positive afterwards ( +7 , from March 19 to 23). Moreover, considerable space was devoted to Chen Shuibian $\left(9,178 \mathrm{~cm}^{2}\right)$, compared to Song Chuyu $\left(2,037 \mathrm{~cm}^{2}\right)$ and even to Lian Zhan $\left(6232 \mathrm{~cm}^{2}\right)$. Lin Rongsan's paper was rather partisan (only $39 \%$ of the surface area is neutral) and proved somewhat opportunistic in initially supporting the existing authorities' candidate, and then rowing in behind the winner.

The Zhongguo shibao was not very partisan: close to $64 \%$ of the surface area devoted to the election studied was neutral. Surprisingly, taking into account the history of the paper whose proprietor, Yu Jizhong, is a mainlander, a former career military man who had been a member of the Central Committee of the Guomindang, the Zhongguo shibao was far from hostile to Chen Shuibian. In any case, following the example of the Ziyou shibao, a certain optimism seems to have come into play: before the election results were made known, Chen Shuibian received 6 positive versus 7 negative occurrences and between March 19 and 23, 8 positive occurrences; amounting to a total score of +7 , as against +3 for Lian Zhan and -2 for Song Chuyu. The Zhongguo shibao also gave enormous importance to Chen Shuibian: $6791 \mathrm{~cm} 3$, as against $2399 \mathrm{~cm} 2$ to Lian Zhan and $342 \mathrm{~cm} 2$ to Song. The other surprise, linked to the first, was that the Zhongguo shibao hardly mentioned Song Chuyu, and when it did it was negatively. 
56 The Linhe bao supported Song Chuyu, who racked up a score of +10 as against -8 to each of his two rivals, Lian Zhan and Chen Shuibian. Once the results of the vote were known, the paper continued to support Song Chuyu, but showed itself less critical of Chen Shuibian. Over half of the surface area devoted to the election under study (57\%) was neutral, without any value judgement on any of the candidates. Of the $11,274 \mathrm{~cm}^{2}$ of partisan surface (43\%), a sizeable space was devoted to Chen: $4961 \mathrm{~cm}^{2}$ predominantly negative, as against $2,598 \mathrm{~cm}^{2}$ predominantly negative pour Lian and $3,715 \mathrm{~cm}^{2}$ predominantly positive to Song.

57 The Zhongyang ribao, an organ of the Guomindang, campaigned predictably, in favour of Lian Zhan, the Nationalist Party's official candidate. The Party's daily wasn't very subtle: Lian Zhan racked up a score of +35 , as against -15 to Song Chuyu and -17 to Chen Shuibian, and only $27 \%$ of the surface studied was neutral. Support for Lian Zhan was seamless, with an entirely positive score, while that of his two rivals was almost entirely negative. $9,063 \mathrm{~cm}^{2}$ of space were devoted to Lian, as against $2,990 \mathrm{~cm}^{2}$ to Chen and $2,328 \mathrm{~cm}^{2}$ to Song.

During the presidential election of March 200, the Zhongguo shibao was the least partisan paper, while the Lianhe bao supported Song Chuyu, the only one of the three candidates to be a mainlander and the most favourable to Beijing. The Zhongyang ribao and the Ziyou shibao campaigned for Lian Zhan. It is hardly surprising that the Zhongyang ribao, the Nationalist Party daily should be a campaigning paper. But the Ziyou shibao, a privately-owned paper, was also very committed: it was much less neutral (39\%) than the Zhongguo shibao (64\%) or even the Lianhe bao (57\%), despite what one might expect given its hatred of Li Denghui. After the election, the Lianhe bao continued to support Song Chuyu, who, on March 312000 created the People First Party (Qinmindang); and displayed redoubled determination against Li Denghui, who was also at the source of a new political organisation, Taiwan tuanjie lianmeng (Taiwan Solidarity Union), created on August 122001.

In the run-up to the presidential election in March 2004, the Ziyou shibao is supporting the incumbent president Chen Shuibian (green camp) whereas the Zhongguo shibao and the Lianhe bao are for his opponents (blue camp). The fourth Taiwanese daily in terms of circulation is a newcomer: the Pingguo ribao (Apple Daily), launched on May 22003 by Hong Kong businessman Jimmy Lai. He established a foothold in Taiwan at the end of May 2000, with the weekly Yi zhoukan (Next), a scandal sheet which has been widely talked about since its creation ${ }^{66}$. The Pingguo ribao, in order to establish itself on the market, was initially priced at 5 \$NT; moreover the Zhongguo shibao and the Lianhe bao dropped their prices from 15 to 10 \$NT on May 1 2003, while the Ziyou shibao remained at 10 \$NT. On June 1 2003, the price of the Pingguo ribao realigned with that of its three competitors. Sold mostly by the copy, the Pingguo ribao, has a high pagination and is studded with colour photographs: it contains about 80 pages as against fifty or so for its three competitors. It publishes three editions: one for Taipei, one for Taizhong and the third for Gaoxiong. The first pages of the editions for the south and centre of the island feature short news items.

At the end of 2003, the Pingguo ribao, which apparently has more appeal in the southern part of Taiwan, claimed a circulation of 400,000 copies a day. Its readership is estimated at les than $10 \%$ (9.8\%), as against $13,7 \%$ for the Lianhe bao, 15,2 \% for the Zhongguo shibao et $19,1 \%$ for the Ziyou shibao. Moreover, its advertising revenues seem much smaller than those of its rivals. The Pinguo ribao is a scandal sheet; although it is 
rumoured that Jimmy Lai tends to favour Lian Zhan, his daily seems likely to have to play a much less important role than its three competitors in the political debate.

61 The daily press in Taiwan is confronted with the same problems as that of most developed countries : concentration of the market and resort to the sensational. In Taiwan, however, these problems seem exacerbated, becuse of the island's past. Prior to 1988 , govenment control forbade the creation of any new newspaper; the permitted dailies thus benefited from a privileged position. This situation gave birth to two big press groups, that of the Lianhebao and that of the Zhongguo shibao. Even though new competitors have appeared since 1988 - in particular the Ziyou shibao and more recently the Pingguo ribao -, these two groups have maintained an important position. The oligopolistic situation prior to 1988 favoured concentration after 1988.

Since the liberalisation, the Taiwanese media have distinguished themselves by an almost total lack of professional ethics. The drift to sensationalism is all the more striking in the absence of any real legal barriers, in particular where respect for privacy is concerned. This legal vacuum is partly explained by the legacy of the authoritarian period. For almost forty years the Taiwanese press was muzzled by means of an enormous armoury of laws. The Taiwanese are therefore particularly suspicious of any legislation, which might in their eyes hobble the freedom of the press.

The political transition in Taiwan suggests the existence of a positive correlation between a free and varied press and democratization. But it was dissident magazines which played a major role in the expression and organisation of the political opposition, and not the dailies authorised by the authorities. The democratization of the regime was to lead to the liberalisation of the sector of the media, which, through their participation in the political debate, then contributed to the consolidation of democracy.

From the beginning, the Nationalist regime had tolerated the existence of privatelyowned newspapers alongside the government ones, while ensuring that they were controlled by persons loyal to the Guomindang. These newspapers, subject to the laws of the market, distanced themselves from the subsidised organs of propaganda, for reasons of profitability among others. In fact, in the space of ten years, the private press overtook the government press. However they did not support the authorities any less: for fear of reprisals, but also because their directors shared the values and the ideals of the Republic of China within which they enjoyed the status of notables. The example of Taiwan in the 1960s should temper the optimism which could arise from the present transformation of the media in the People's Republic: the commercialisation of the sector will not inevitably give rise to freedom of the press.

\section{NOTES}

1. Baojin means, literally, " prohibitions concerning newspapers ".

2. This was directive $n^{\circ} 3148$ which stipulated in its seventh point: «In the province of Taiwan, newspapers and magazines have already reached saturation point. In order to 
save paper, new registrations of newspapers, magazines and press agencies must henceforth be very strictly curtailed " ". Xinwen yewu shouce (Manual for the information professions), Taizhong, Taiwan sheng zhengfu xinwenchu, 1983, p. 17. 3. The 1952 law incorporated, after four years of revision, the major points in the Guomindang's 1930 and 1937 laws on publications, prior to the 1947 Constitution, which were in turn inspired by the Yuan Shikai law on publications of 1914, and the Qing law of 1906.

4. The law on publications was amended again on August 101973.

5. To crack down on the press, the Nationalist regime had at its disposal a number of other texts, not directly concerning the press, such as the law on national conscription or the sedition law.

6. For half-sheet or tabloid papers, one and a half sheets is equivalent to twice as much, or 12 pages.

7. Between 1951 and 1960, seven newspapers were given publication permits. These however were publications with a limited readership, some of which already existed before being registered.

8. At the end of the period of Japanese colonisation (1895-1945) there remained only one newspaper in Taiwan which resulted from the fusion of 6 dailies, the Taiwan xinbao (or Taiwan Shinpo). It was taken over by the provincial authorities and reappeared under the title of Taiwan xinsheng bao on the day of Liberation, October 25 1945. After the Nationalist retreat to Taiwan, a major part of the team from the Shanghai Shenbao, which the Guomindang had taken over in 1946, joined the Taiwan xinsgeng bao.

9. The Zhongyiang ribao, which was brought over from mainland China, began to appear in Taipei on March 12 1949. Officially the paper had been created on January 11928 in Shanghai. But in reality, it had appeared under the Guomindang government in Wuhan. 158 issues appeared in Hankou between March and September 1927. Wang Hongjun, "Kangzhan qianhou shiqi baoye zhi yanlun jingshen" (Opinion in the press at the time of the war of resistance against Japan), in Wang Hongjun, ed., Xinwen lilun de Zhongguo lishi guan (Historical Perspective on Chinese Journalism), Taipei, Yuanliu, 1998, pp. 397-460.

10. From 1945 to the early 1950 s, between 910,000 and 2 million people left mainland China for Taiwan. They became the mainland community on the island, a minority within the Taiwanese population estimated to be 6 million people in 1946 and 7.87 million in 1951. These refugees and their descendants have monopolised power at the expense of the islanders or native Taiwanese (Bendiren). See especially Fiorella Allio «The dynamics of the Identity Issue in Taiwan » China Perspectives, $N^{\circ} 28$, March-April 2000, pp. 43-50.

11. Institutional advertising at that time made up most of the advertising and appeared only in the Zhongyang ribao and the Taiwan xinsheng bao. In 1954, and again in 1958, the Association of private newspapers tried expand its demands to the political field.

12. In 2003, the Lianhebao group included five dailies in Taiwan : as well as the Lianhe bao, an economic daily, the Jingji ribao (Economic Daily News) created on April 201967 ; the Minsheng bao (Min Sheng Daily) launched on February 18 1978, and specialising in daily life and leisure ; an evening daily, the Lianhe wanbao (United Evening News) launched on February 221988 ; a newspaper specialising in people news and aimed at young people, the Xingbao (Star) launched on July 25 1999. It also has three dailies abroad: the World Journal (Shijie ribao) in the United States and in Canada, launched in 
1976 ; the Europe Journal (Ouzhou ribao) in France, created in 1982 ; and The Universal Daily News (Shijie ribao) in Thailand, which was taken over in 1986.

13. In 2003 this group included, as well as its flagship, the Zhongguo shibao, created on October 2 1950, an economic daily, the Gongshang shibao (Commercial Times), launched on december 1 1978, and an evening daily, the Zhongshi wanbao (China Times Express), launched on March 5 1988. The Zhongguo shibao group also owns some magazines.

14. "Zhongguo shibao" sishi nian (Forty Years of The China Times), Taipei, Zhongguo shibao she, 1990, $409 \mathrm{p}$.

15. The importance given to education by the Nationalist regime was also dictated by politicalconsiderations. It was a question of imposing Mandarin (guoyu) on the island population, most of whom spoke minnanhua and Japanese after fifty years of Japanese colonisation.

16. Zhonghua Minguo guanggao nianjian 94-95 (Annual of Advertising in the Republic of China 1994-1995), Taipei, Taibeishi guanggao daili shangye tongye gonghui, 1995, p.51. Zhonghua Minguo xinwen nianjian 80 (Annual of the Media in the Republic of China 1991), Taipei, Zhongguo xinwen xuehui, 1991, p. 202 et p. 271.

17. In 1977, one had the choice of having a small ad appear in the Lianhe bao either «nationally » or in one of its six local editions. In 2000, the Lianhe bao had 23 editions.

18. Hourly productivity of manual typesetting was about 1,500 signs for an alphabetical language, as against 1,200 for Chinese. The productivity of linotype could reach 12,000 signs.

19. For the Lianhe bao, at the beginning of automation in the 1960s, hourly productivity reached 4,800 signs. In the early 1980 s, with computerisation, it rose to 7,500 signs.

20. Chen Guoxiang, Zhu Ping, Taiwan baoye yanjin 40 nian (Forty Years of Development in the Taiwanese Press), Taipei, Zili wanbao, 1987.

21. Chen, Zhu, Taiwan baoye yanjin 40 nian, p. 182. This figure is most probably an overestimate. In Chen, Zhu, p. 200, the total circulation, which continued to grow afterwards, is estimated at only 3.5 million in 1983.

22. Wu Sanlian is a key personality in the Tainan bang. See Gilles Guiheux, Les Grands Entrepreneurs privés à Taiwan. La main visible de la prospérité, Paris, CNRS éditions, 2002. See also "Zili wanbao" 40 nian (Forty Years of The Evening Independent), Taipei, Zili wanbao, 1989.

23. After a reorganisation in 1981, the circulation of the Zili wanbao more than quadrupled between 1982 and 1987, reaching up to three-quarters of a market estimated at 300,000 copies.

24. In 1985, the Minzhon ribao was suspended for 7 days by the authorities for « communist propaganda ». Just before January 1 1988, its circulation was around 110,000 copies.

25. The total circulation of opposition magazines is estimated at 150,000 copies per month in 1978, a figure which remained more or less constant for the next ten years. 26. Ferhat-Dana Samia, Le Dangwai et la démocratie à Taiwan, Paris, L'Harmattan, 1998. Geoffroy Claude, Le Mouvement indépendantiste taiwanais, Paris, L'Harmattan, 1997. 27. Chen, Zhu, Taiwan baoye yanjin 40 nian, p. 200.

28. The circulation of the Jingji ribao is about 200,000 copies, that of the Gongshang shibao 100,000 copies and that of the Minsheng bao 400,000 copies. "Taiwan baoye chuanqi" (Legends of the Taiwanese Press), Caixun, April 1987, n61, pp. 150-269. 29. Between 1991 and 2001, the percentage of subscription sales in overal sales fell from $62 \%$ to $34.4 \%$. 
30. Zhonghua minguo guanggao nianjian 2001-2002 (Advertising Yearbook of Taiwan, The Republic of China, 2001-2002), Taipei, Taibeishi guanggao daili shangtongye gonghui, 2003, pp.222-240.

31. In 1997, the two groups' dailies took in $79 \%$ of the advertising market : $48 \%$ for the Lianhebao group's papers, whose share thus declined significantly in the last few years, and $31 \%$ for those of the Zhngguo shibao group.

32. ${ }^{32}$ On March 26 2000, the Zhongguo shibao comprised no less than 80 pages.

33. Another evening paper, Jinbao (Power), which appeared in Taipei on July 26 1999, ceased publication at the same period. There remained the two evening dailies published by the Lianhebao and Zhongguo shibao groups. At the end of 2003 the evening paper market was struck by disaster: many readers bought these papers for the stockmarket results, but the results were now given in real time on the Internet and on the cable TV channels.

34. The paper, which was then called Ziqiang ribao, took on its new title on January 1 1980. The origins of this daily go back to the Taidong xinbao (The New Taidong Daily), created on December 20 1948, which was successively transformed into Yuandong ribao (the Far-Eastern Daily), Dongsheng ribao (The Voice of The East), Taisheng ribao (The Voice of Taiwan), Dahan ribao (The Great Han Daily), before becoming the Ziqiang ribao (The Reenforcement Daily).

35. Lin Ke, "Lin Rongsan, Wu Amin fenli jingying Ziyou ribao" (Lin Rongsan and Wu Amin are doing their best for the Ziyou ribao), Caixun, April 1987, n61, pp. 224-227. 36. The clandestine lotteries called dajiale (the happiness of all) pirated the official Chinese national Lottery created in 1950. At each draw, seven tickets of the National Lottery won 1 Million \$NT. The clandestine palayers bet on the last two numbers of these seven tickets. The phenomenon grew unbelievably widespread : on the day of the draw, the island's economy is ground to a partial halt, businesses went bankrupt because of the gambling compulsion of their owners, swindles of all sorts proliferated, to say nothing of other exactions such as the violation of tombs to obtain the winning numbers from Beyond. The authorities were forced to adopt a radical solution: at the end of January 1988, Lottery draws were suspended.

37. Editorial reform was carried out under the aegis of Yan Wenshan, a Taiwanese from Gaoxiong, who had been, in particular, editor-in-chief of the Zili wanbao.

38. Another daily launched on January 101990 seems to be enduring: the Dacheng bao (The Great Daily News), with the same market positioning as the Lianhebao group's Minsheng bao. On April 18 1997, it divided into two different papers, one devoted to sport, the other to entertainment. The two have since joined up again. This daily belongs to Lin Xie Hanjian, a sister-in-law of Lin Rongsan, the boss of the Ziyou shibao. Both belong to the "Sanchong bang ", Sanchong being a city in the district of Taipei, northwest of the capital.

39. Prior to 1988, because of the quotas on paper and the limited pagination imposed by the Nationalist regime, circulation was estimated on the basis of each paper's consumption of paper.

40. This was AC Nielsen.

41. Xi Xiande ed., Taiwan xinwen shiye wenti jiexi (Analysis of the problems of the Taiwanese press), Taipei, Wenzhan, 1992, p. 124.

42. Diao Manpeng, You Changshan, "Di yi dabao, jinzi dazao?" (Does the number 1 daily produce gold?), Tianxia, July 1 1997, n¹94, pp. 60-78. 
43. The distribution of free copies has always existed, Tianxia explained, but it generally amounted to $1 \%$ to $5 \%$ of circulation, whereas the Ziyou shibao was said to go as high as $30 \%$ on occasion. The avalanche of free copies was also visible in the Zhonghua minguo guanggao nianjian 1997-1998, p. 167: their number more than tripled between 1991 and 1997, rising from $1.1 \%$ to $3.6 \%$. But the annual did not specify which paper or papers originated the increase.

44. Between March 13 and 26 2000, the Zhongguo shibao published 427.5 pages of advertising, the Lianhe bao 309.25, and the Ziyou shibao 253.5. Data compiled by the author.

45. Such as the Lianh bao's « 3-3-3 » operation: for 33,300 \$NT, the paper, in association with an automobile manufacturer, offered a 33 month subscription, with as a gift, a car. In the course of this campaign, some 50,000 cars were given away, one third to new readers, and two thirds to former subscribers in an attempt to win their loyalty. The Zhongguo shibao followed suit: in partnership with another car company it offered a three-year subscription and a car for 36,000 \$NT.

46. Jimmy Lai, from the People's Republic, made a fortune in textiles with the Giordano brand of clothes. After the events of Tian'anmen he went into publishing by creating, in Hong Kong in 1989, the weekly Yizhoukan (Next). The Pingguo ribao, just like Next, resembles the English gutter press, whose main representative is The Sun. But the success of Jimmy Lai's papers in the former British colony is also explained by their irreverent attitude towards Beijing.

47. The Media Council of the Republic of China (Zhonghua minguo xinwen pingyi weiyuanhui) is an organ for self-regulation of the profession founded in 1963, but devoid of any real power.

48. Shuang George Kuo-ning, Political Communication and Political Culture: Government and Press Relations in Taiwan, doctoral thesis in philosophy, University of Maryland, 1993,

p. 167.

49. Shao Yuming, "Tan zhengfu fayanren de yunzuo" (On the functioning of the government's spokesman), in "Fayanren yu gongong guanxi zhuanji" (Dossier on spokesmen and public relations), Baoxue, February 1991, vol.VIII, n4, pp. 20-23.

50. Kuai Liang, "Zhengdang fayanren mianmianguan - Fang Guomindang wengonghui Zhu Jiying zhuren tan zhengdang fayanren" (Spokesman of a political party: Interview with Zhu Jiying, Director of the department of Cultural Affairs of the Guomindang), Baoxue, February 1991, pp. 24-28.

51. See Huang Nian ed., "Lianhe bao" sishi nian (Forty Years of the Lianhe bao), Taipei, Lianjing, 1991, 255 p.; Wang Limei, Baoren Wang Tiwu. Lianhebao de gushi (Press Baron Wang Tiwu. The History of the Lianhebao group), Taipei, Tianxia wenhua, 1994, 429 p.; Wang Tiwu, Wo yu xinwen shiye (Journalism and I), Taipei, Lianjing, 1991, 231 p. ; as well as Lin Fumei, Taiwan zhengjing xiluo zhongde baoye fazhan. Yi Lianhe bao wei li, tantao meijie shuangyuan tezhi dui baoye zuzhi zuowei de yingxiang (The development of the press in the political and economic framework of Taiwan. Research into the double nature of the media and its impact on the organisation of the press, using the example of the Lianhe bao), doctoral thesis, Institute of Research into Journalism, National Political Science University, Taipei, 1998.

52. The President of a daily in Gaoxiong, the Zhongguo chenbao.

53. A book on the boycott published by the Lianhebao group has been very useful to us: Rang lishi lai caipan (History Will Judge), Taipei, Lianhebao she, 1994, 195 pp. The documents reproduced in the book do not seem questionable. However a certain bias 
springs from the very selection of the facts, since some have been chosen rather than others... as for the commentaries, they do not pretend to be objective, but seek to explain the positions of the Lianhe bao. Pages 15-16 of Rang lishi lai caipan contain the official report of the debate within the Permanent Committee, published by the Guomindang.

54. This was in the midst of the election campaign for the legislative Yuan.

55. The complete text addressed to the Guomindang is reproduced in Rang lishi lai caipan, pp. 54-55.

56. Its owner, Zhang Rongfa, was close to Li Denghui.

57. Those Taiwanese who had forged links with Nationalist regime, in particular on visits to the mainland before 1949 , are nicknamed banshan, i.e. « semi-mainlanders », a reference to the mainlanders called ashan by the island's inhabitants: litterally « people from beyond the mountains ".

58. Jean-Pierre Cabestan, Taiwan-Chine populaire : l'impossible réunification, Paris, IfriDunod, 1995, p. 84.

59. In the eyes of the Lianhebao group, Li Denghui's involvement in the boycott was direct: his nephew, Lai Guozhou, a university professor, is said to have taken over. Interviews with the group's directors in April and May 2000.

60. The Lianhe bao complained in particular of being ostracised by the President : Li Denghui is supposed to have favoured his friend Lin Rongshan's Ziyou shibao, giving it all kinds of information first, while " forgetting » to invite the Lianhe bao to press conferences. The Ziyou shibao seems to have been often better informed than the Guomindang's Zhongyang ribao.

61. In 1989, Song Chuyu was appointed Secretary General of the Nationalist Party by Li Denghui. But relations between the two men deteriorated rapidly. In 1994, Song Chuyu was elected Governor of Taiwan for four years, and in August 1997, in the election of the Central Committee of the $15^{\text {th }}$ Congress of the Guomindang, he received the largest number of votes. He thus became Li Denghui's possible successor, and the direct rival of his protégé, Lian Zhan.

62. As a comparison, Li Denghui's score in 1996 (54\%) surpassed that of all the other candidates together.

63. Between March 13 and 23 2000, the Lianhe bao whose average pagination was 57.72 pages, devoted an average of 8.9 pages per day ( $16.9 \%$ of the surface) to the election. The Zhongguo shibao with an average pagination of 57,09 pages devoted 8,3 pages $(14,5 \%)$. Ziyou shibao, with an average pagination of 52,18 pages, devoted 9,2 pages (17,6\%). Le Zhongyang ribao, with an average pagination of 27,63 pages, devoted 7 pages $(25,3 \%$ of the surface).

64. When an article referred to 2 or 3 candidates, we simply divided the surface by 2 or 3 , without any weighting.

65. The dissension between the two is said to date back to 1992 : while Song Chuyu was Secretary General of the Guomindang, he did not support Lin Rongsan's candidacy to the Control Yuan. From this period also dates a tenacious grudge of Lin Rongsan's towards the Lianhe bao and the Zhongguo shibao, who had branded him a " racketeer ». 66. Next and Apple Daily, which Jimmy Lai owns in Hong Kong, are completely independent from the Taiwanese titles. 